\title{
PENGARUH KOMPETENSI PENDAMPING PROGRAM KELUARGA HARAPAN (PKH) DAN UMKM PESERTA TERHADAP PENINGKATAN PENDIDIKAN ANAK PESERTA PKH DI KECAMATAN CIRUAS KABUPATEN SERANG
}

\author{
Khaeruman \\ Universitas Bina Bangsa Banten \\ khaeruman.oce@gmail.com \\ Ahmad Mukhlis \\ Universitas Bina Bangsa Banten \\ ahmuk999@gmail.com
}

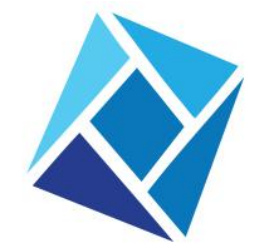

Jurnal Nusantara

Aplikasi Manajemen Bisnis

http://ojs.unpkediri.ac.id/index.php/mana jemen/index

E-ISSN : 2528-0929

P-ISSN : 2549 - 5291

Diterima: 5 Juni 2018

Revisi : 29 Juni 2018

Disetujui: 10 Oktober 2018

https:DOI 10.29407/nusamba.v3i2.12144
Abstract

This research has a purpose to know and test the influence between Competency Assistant Program of Family of Hope (PKH) and UMKM together to increase education of children of $P K H$ participant in District of Ciruas Regency of Serang. While the research method using quantitative research approach. Based on the results of the study showed that the results of simple correlation analysis $(r)$ using SPSS program version 22 obtained value of 0.144, meaning that the closeness of the relationship between variables Competency Assistant PKH and SMEs on Education Children Participant PKH is strong because the value of $0.144>0.5$ and are in the low range ie $(0.00$ 0.20). The amount of independent variable contribution is determined by the coefficient of determination and obtained calculation of $14.4 \%$, meaning that the Competency Assistance variable of PKH and UMKM affects the Education of Child Participant PKH 14.4\%, and the rest $85.6 \%$ is influenced by other variables not explained in this research model. While the results of hypothesis testing using SPSS program version 22 obtained Fcount value of 12.969 greater than Ftabel of 3.10 and Sig $F$ value of 0.000 smaller than 0.05 then there is a significant influence between Competency Assistance PKH and UMKM simultaneously to the Education of Participant Children PKH in Kecamatan Ciruas, Serang regency.

Keywords: Competence, UMKM and Education

Abstrak

Penelitian ini memiliki tujuan untuk mengetahui dan menguji pengaruh antara Kompetensi Pendamping Program Keluarga Harapan (PKH) dan UMKM secara bersama-sama terhadap peningkatan pendidikan anak peserta PKH di Kecamatan Ciruas Kabupaten Serang. Sedangkan metode penelitian mempergunakan pendekatan penelitian kuantitatif. Berdasarkan hasil penelitian menunjukkan bahwa dari hasil analisis korelasi sederhana (r) menggunakan program SPSS versi 22 didapat nilai sebesar 0,144, artinya bahwa keeratan hubungan antara variabel Kompetensi Pendamping PKH dan UMKM terhadap Pendidikan Anak Peserta PKH adalah kuat karena nilai 0,144 $>0,5$ dan berada pada rentang rendah yaitu $(0,00-0,20)$. Besarnya kontribusi variabel bebas ditentukan oleh koefisien determinasi dan didapat perhitungan sebesar $14,4 \%$, berarti variabel Kompetensi Pendamping PKH dan UMKM mempengaruhi Pendidikan Anak Peserta PKH sebesar 14,4\% , dan sisanya 85,6\% dipengaruhi oleh variabel-variabel lain yang tidak dijelaskan dalam model penelitian ini. Sedangkan hasil uji hipotesis menggunakan program SPSS versi 22 diperoleh nilai $F_{\text {hitung }}$ sebesar 12,969 lebih besar dari $F_{\text {tabel }}$ sebesar 3,10 dan nilai Sig F sebesar 0,000 lebih kecil dari 0,05 maka terdapat pengaruh signifikan antara Kompetensi Pendamping $\mathrm{PKH}$ dan UMKM secara simultan terhadap Pendidikan Anak Peserta PKH di Kecamatan Ciruas Kabupaten Serang.

Kata Kunci : Kompetensi, UMKM dan Pendidikan 


\section{PENDAHULUAN}

Manusia sebagai makhluk hidup memiliki ciri khasnya tersendiri yang tidak mungkin sama dengan makhluk lainnya. Sejalan dengan itu Louis Leahy mengungkapkan. Pertama, kekhasan makhluk hidup adalah asimilasi artinya makhluk hidup berkembang dan mengembangkan diri dengan mengubah apa yang dimakan dan dicerna menjadi substansinya sendiri. Kedua, makhluk hidup dapat memulihkan dirinya dari berbagai kemungkinan yang telah menimpanya. Ketiga, reproduksi makhluk hidup dapat melipatgandakan dirinya. Keempat, bereaksi makhluk hdup bereaksi atas pengaruhpengaruhnya yang mengkondisikan eksistensinya (Leahy, 2001)

Program Keluarga Harapan adalah program pemberian dana bantuan tunai kepada Rumah Tangga Sangat Miskin (RTSM) sepanjang mereka memenuhi persyaratan yang terkait dengan upaya peningkatan kualitas sumberdaya manusia (SDM), yaitu pendidikan dan kesehatan (Tim Penyusun, 2009). UMKM Merupakan salah satu komitmen Pemerintah terhadap Usaha Mikro Kecil dan Menengah (UMKM) dalam struktur permodalan dan keterbatasan untuk memperoleh akses terhadap sumber-sumber permodalan juga sudah banyak yang dilakukan. Khususnya memotivasi agar peserta melakukan untuk meningkatkan partisipasi pendidikan dasar wajib sembilan tahun.

Oleh karena itu, maka peran maksimal pendamping program ini dibutuhkan dengan kompetensi pendamping yang memadai. Kompetensi adalah perpaduan dari pengetahuan, keterampilan, nilai dan sikap yang direfleksikan dalam kebiasaan berfikir dan bertindak (Mulyasa, 2011)

Masalah-masalah yang dapat dirumuskan adalah apakah ada pengaruh yang signifikan antara Kompetensi Pendamping Program Keluarga Harapan (PKH) dan UMKM secara bersama-sama terhadap peningkatan pendidikan anak peserta PKH di Kecamatan Ciruas Kabupaten Serang?.

Berpangkal dari uraian di atas, maka penelitian ini diarahkan untuk memahami lebih jauh tentang "Pengaruh Kompetensi Pendamping Program Keluarga Harapan (PKH) dan UMKM Peserta terhadap Peningkatan Pendidikan Peserta PKH di Kecamatan Ciruas Kabupaten Serang”.

\section{TINJAUAN PUSTAKA}

\section{Program Keluarga Harapan}

Program Keluarga Harapan (PKH) merupakan program percepatan penanggulan kemiskinan dan pengembangan sistem jaminan sosial melalui pemberian bantuan tunai bersyarat kepada Rumah Tangga Sangat Miskin (RTSM) atau Keluarga Penerima Manfaat (KPM).

\section{Kompetensi Pendamping Program Keluarga Harapan}

Kompetensi menurut Mugniesyah adalah spesifikasi pengetahuan dan keterampilan dan aplikasi keduanya (dalam suatu industri atau dalam pekerjaan industri atau tingkat industri) terhadap standar kinerja yang dibutuhkan dalam pekerjaan (Mugniesyah, 2005). Peran utama seorang pendamping adalah membantu menghidupkan dan mengembangkan kelompok masyarakat sebagai wadah peningkatan kesejahteraan masyarakat miskin.

\section{Usaha Mikro Kecil dan Menengah UMKM}

Usaha Mikro Kecil dan Menengah (UMKM) adalah peluang usaha produktif milik orang perorangan atau badan usaha perorangan yang memenuhi kriteria usaha mikro sebagaimana diatur oleh undang-undang. Dimana UMKM merupakan usaha ekonomi produktif yang berdiri sendiri, yang dilakukan oleh orang perseorangan atau badan usaha yang bukan merupakan anak perusahaan atau cabang perusahaan yang dimiliki, dikuasai, atau menjadi bagian baik langsung maupun tidak langsung.

\section{Pendidikan Anak Peserta PKH}


Pendidikan merupakan mesin pertumbuhan yang diletakkan pada kualitas dan kuantitas pendidikan di sebuah negara. Agar pendidikan berkontribusi secara signifikan terhadap pertumbuhan ekonomi dan pembangunan, maka ia harus memiliki kualitas yang tinggi untuk memenuhi tuntutan kebutuhan skill dari ekonomi.

\section{METODE PENELITIAN}

\section{Tempat dan Waktu Penelitian}

Lokasi penelitian di Kecamatan Ciruas Kabupaten Serang Provinsi Banten. Lokasi tersebut memberikan kemudahan akses sehingga memudahkan peneliti dalam memperoleh dan mengolah data yang berlangsung selama 1 tahun waktu efektif di tahun 2018.

\section{Metode Penelitian}

Metode penelitian pada dasarnya merupakan cara ilmiah untuk mendapatkan data dengan tujuan dan kegunaan tertentu. Penelitian ini penulis mempergunakan pendekatan penelitian kuantitatif (Sugiyono, 2014)

\section{Populasi dan Sampel}

Populasi adalah wilayah generalisasi yang terdiri atas obyek/subyek yang mempunyai kualitas dan karakteristik tertentu yang ditetapkan peneliti untuk dipelajari dan ditarik kesimpulannya (Sugiyono, 2014). Populasinya adalah peserta PKH di Kecamatan Ciruas Kabupaten Serang berjumlah 1.575 peserta PKH. Sampel adalah bagian dari jumlah dan karakteristik yang dimiliki oleh (Sugiyono, 2014). Sampel dapat dihitung berdasarkan rumus Slovin, yaitu :

$$
n=\frac{N}{1+N(e)^{2}}
$$

\section{Dimana :}

$\mathrm{n}=$ Ukuran sampel

$\mathrm{N}=$ Ukuran populasi

$\mathrm{e}=$ Persen kelonggaran ketidaktelitian karena kesalahan pengambilan sampel yang masih dapat ditolelir misalnya $10 \%=0,1$

$\mathrm{I}=$ Konstan

Populasi yang digunakan oleh adalah sebanyak 1.575 orang peserta PKH.

$$
\begin{aligned}
\mathrm{n} & =\frac{N}{1+N(e)^{2}}=\frac{1575}{1+1575(0,10)^{2}}=\frac{1575}{1+1575 .(0,010)}=\frac{1575}{1+15,75} \\
& =\frac{1575}{16,75}=94,02 \rightarrow 94 \text { peserta PKH }
\end{aligned}
$$

Berdasarkan hasil perhitungan tersebut sampel sebanyak 94 peserta $\mathrm{PKH}$.

\section{Prosedur Penelitian}

\section{a. Uji Validitas dan Reliabilitas}

Dalam penelitian ini digunakan rumus teknik korelasi product moment untuk dapat menghitung nilai korelasi yaitu:

$$
\mathbf{r}_{\mathrm{xy}}=\frac{n \sum x y-\left(\sum x\right)\left(\sum y\right)}{\sqrt{\left(n \sum x^{2}-\left(\sum x\right)^{2}\right\}\left(n \sum y^{2}-\left(\sum y\right)^{2}\right\}}}
$$


Kriteria dengan taraf signifikansi $5 \%$ atau 0,05 ;

- Koefisien product moment $\left(\mathrm{r}_{\text {hitung }}\right)>\left(\mathrm{r}_{\text {tabel }}\right)$ memiliki arti bahwa kuesioner dapat dinyatakan valid.

- Koefisien product moment $\left(\mathrm{r}_{\text {hitung }}\right)<\left(\mathrm{r}_{\text {tabel }}\right)$ memiliki arti bahwa kuesioner dapat dinyatakan tidak valid.

Pengujian Reliabilitas yang lakukan dapat menunjukkan sejauh mana pengukuran tersebut dapat memberikan hasil yang dapat diandalkan dan tetap konsisten. Penelitian ini digunakan rumus teknik alpha (cronbach) :

$$
\mathrm{r}=\left(\frac{n}{n-1}\right)\left(1-\frac{\sum \sigma_{t}^{2}}{\sigma_{t}^{2}}\right)
$$

Kriteria dengan taraf signifikansi $5 \%$ atau 0,05

- $r_{\text {hitung }}>\mathrm{r}_{\text {tabel }}$, berarti kuesioner dinyatakan reliabel.

- $\mathrm{r}_{\text {hitung }}<\mathrm{r}_{\text {tabel}}$, berarti kuesioner dinyatakan tidak reliable.

b. Teknik Analisis Data

1) Uji Asumsi Klasik

a. Uji Normalitas

Uji normalitas bertujuan untuk mengetahui bahwa sebaran data penelitian berdistribusi normal atau tidak. Pada diagram normal probability plot terlihat juga titiktitik yang menyebar dan kesemuanya menunjukkan bahwa model berdistribusi normal.

\section{b. Uji Heteroskedastisitas}

Metode yang digunakan adalah mengkorelasikan nilai absolut residualnya dengan masing-masing variabel independen. Jika hasil nilai signifikansi $>$ nilai $\alpha=0,05$, maka model tidak mengalami heteroskedastisitas.

\section{c. Uji Multikolinieritas}

Uji Multikolinieritas merupakan uji yang digunakan untuk mengetahui apakah di dalam persamaan regresi terjadi gejala multikolinieritas atau tidak. Jika ada berarti sesama variabel bebasnya terjadi korelasi.

\section{2) Analisis Korelasi}

Metode analisis korelasi dapat diketahui hubungan antara variabel dengan melihat pearson correlation.

\section{3) Uji Regresi Linear Berganda}

\section{HASIL PEMBAHASAN}

\section{a. Pengujian Persyaratan Analisis Data}

b) Uji Instrumen Variabel

\section{Uji Validitas dan Uji Reliabilitas}

Dari nilai-nilai kuesioner yang telah diolah di dapat nilai korelasi pearson setiap kuesioner pada tiap variabel adalah sebagai berikut:

Variabel Pendidikan Anak Peserta PKH 
Tabel 1 : Validitas Kuesioner Pendidikan Anak Peserta Item-Total Statistics

\begin{tabular}{cccc}
\hline Item & $\begin{array}{c}\text { Corrected Item-Total } \\
\text { Correlation (nilai } \mathbf{r}_{\text {pearson }} \text { ) }\end{array}$ & $\begin{array}{c}\text { Nilai } \\
\mathbf{r}_{\text {tabel }}\end{array}$ & Simpulan \\
Y.1 & .683 & .2028 & Valid \\
Y.2 & .650 & .2028 & Valid \\
Y.3 & .473 & .2028 & Valid \\
Y.4 & .697 & .2028 & Valid \\
Y.5 & .757 & .2028 & Valid \\
Y.6 & .785 & .2028 & Valid \\
Y.7 & .725 & .2028 & Valid \\
Y.8 & .565 & .2028 & Valid \\
Y.9 & .504 & .2028 & Valid \\
Y.10 & .502 & .2028 & Valid \\
\hline
\end{tabular}

a. Variabel Kompetensi Pendamping PKH

Tabel 2 : Validitas Kuesioner Kompetensi Pendamping Item-Total Statistics

\begin{tabular}{cccc}
\hline Item & $\begin{array}{c}\text { Corrected Item-Total } \\
\text { Correlation (nilai } \mathbf{r}_{\text {pearson }} \text { ) }\end{array}$ & $\begin{array}{c}\text { Nilai } \\
\mathbf{r}_{\text {tabel }}\end{array}$ & Simpulan \\
\hline X1.1 & .754 & .2028 & Valid \\
X1.2 & .532 & .2028 & Valid \\
X1.3 & .704 & .2028 & Valid \\
X1.4 & .522 & .2028 & Valid \\
X1.5 & .595 & .2028 & Valid \\
X1.6 & .566 & .2028 & Valid \\
X1.7 & .765 & .2028 & Valid \\
X1.8 & .908 & .2028 & Valid \\
X1.9 & .526 & .2028 & Valid \\
X1.10 & .754 & .2028 & Valid \\
\hline
\end{tabular}

b. Variabel UMKM

Tabel 3 : Validitas Kuesioner UMKM Item-Total Statistics

\begin{tabular}{cccc}
\hline Item & $\begin{array}{c}\text { Corrected Item-Total } \\
\text { Correlation (nilai } \mathbf{r}_{\text {pearson }} \text { ) }\end{array}$ & $\begin{array}{c}\text { Nilai } \\
\mathbf{r}_{\text {tabel }}\end{array}$ & Simpulan \\
\hline X2.1 & .753 & .2028 & Valid \\
X2.2 & .550 & .2028 & Valid \\
X2.3 & .856 & .2028 & Valid \\
X2.4 & .575 & .2028 & Valid \\
X2.5 & .753 & .2028 & Valid \\
X2.6 & .490 & .2028 & Valid \\
X2.7 & .752 & .2028 & Valid \\
X2.8 & .613 & .2028 & Valid \\
X2.9 & .664 & .2028 & Valid \\
X2.10 & .455 & .2028 & Valid \\
\hline
\end{tabular}

Uji reliabilitas variabel, yaitu pengujian data yang dilakukan uji konsistensi internal dengan koefisien Cronbach Alpha. Untuk instrument yang berupa angket maka $\mathrm{r}_{a l p h a}$ diperoleh indeks reliabilitas harus diatas nilai 0,6 untuk dinyatakan reliabel.

Tabel 4 : Reliabilitas Variabel (Reliability Statistics) 


\begin{tabular}{lccc}
\hline \multicolumn{1}{c}{ Variabel } & $\begin{array}{c}\text { Cronbach's } \\
\text { Alpha Based On } \\
\text { Standardized } \\
\text { Items }\end{array}$ & $\begin{array}{c}\text { N of } \\
\text { Items }\end{array}$ & Simpulan \\
Pendidikan Anak & .821 & 10 & Reliabel \\
Kompetensi Pendamping & .853 & 10 & Reliabel \\
UMKM & .846 & 10 & Reliabel \\
\hline
\end{tabular}

Berdasarkan Tabel 4 diatas, menunjukkan nilai cronbach alpha untuk variabel Pendidikan Anak Peserta PKH sebesar $0.821\left(\mathrm{r}_{a l p h a}>0,6\right)$, Kompetensi Pendamping PKH sebesar $0.853\left(\mathrm{r}_{a l p h a}>0,6\right)$ dan UMKM sebesar $0.846\left(\mathrm{r}_{\text {alpha }}>0,6\right)$ yang mana variabelvariabel tersebut diatas 0,6 , hal ini berarti bahwa jawaban responden terhadap kuesioner penelitian adalah reliable.

\section{c) Uji Asumsi}

\section{Uji Normalitas}

Kurva nilai residual terstandarisasi dikatakan menyabar dengan normal apabila nilai Asymp. Sig. (2-tailed) $>\alpha$ dengan diharapkan nilai residual akan menyebar normal dengan nilai rata-rata $=0$, yang artinya frekuensi nilai residual berada disekitar nol memiliki fekuensi yang cukup besar daripada nilainilai selisih yang ekstrim.

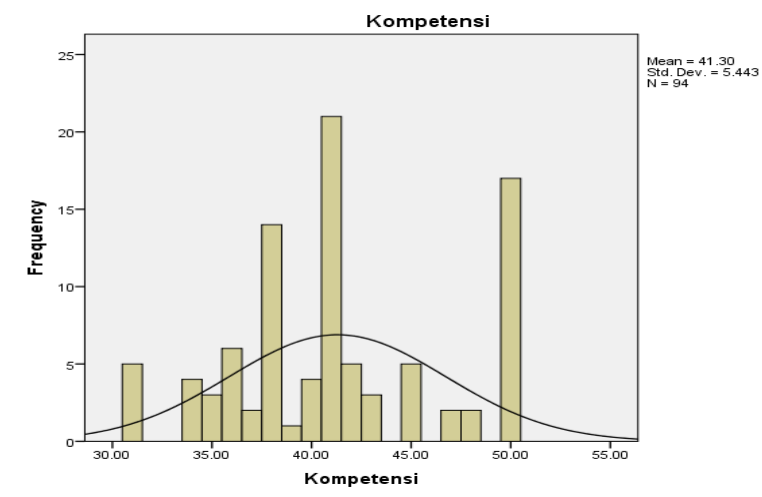

Gambar 1 : Uji Asumsi Normalitas Histogram Kompetensi Pendamping

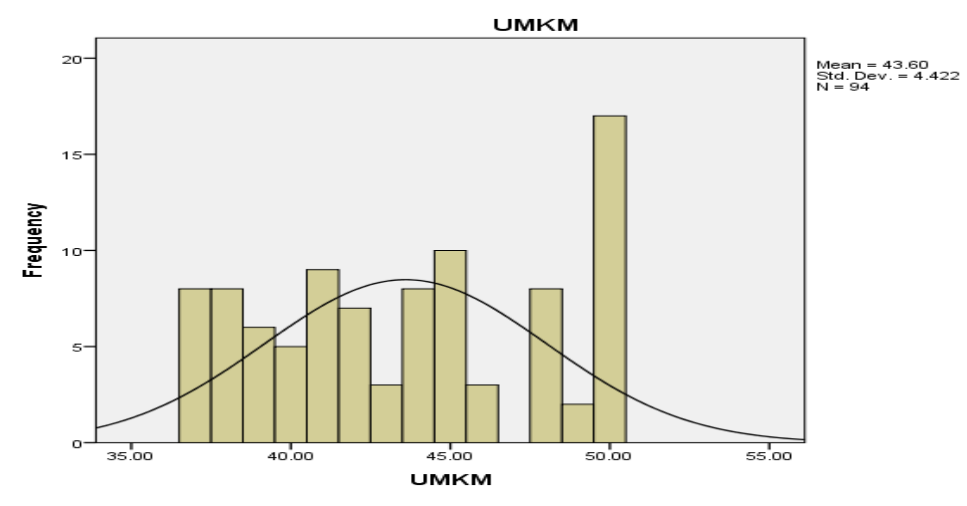

Gambar 2 : Uji Asumsi Normalitas Histogram UMKM 


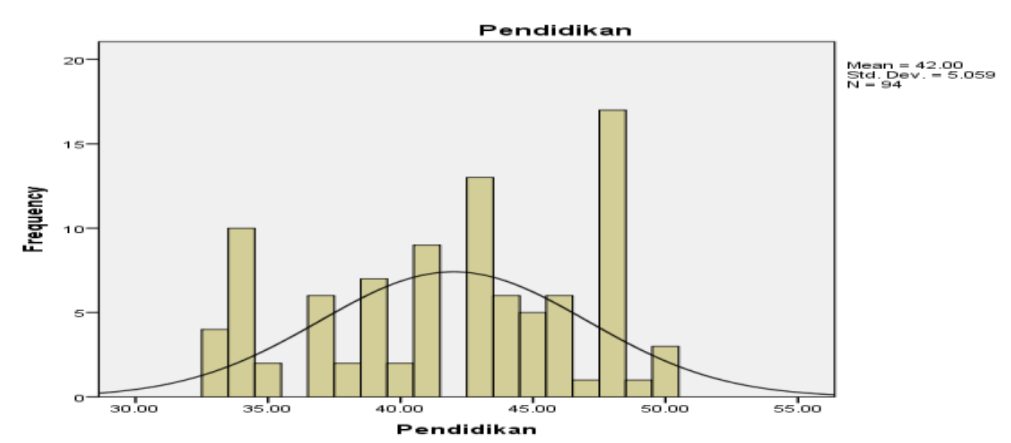

Gambar 3 : Uji Asumsi Normalitas Histogram Pendidikan Anak Peserta

Berdasarkan Gambar bahwa kurva membentuk suatu lonceng (bell-shaped curve) yang kedua sisi tersebut melebar sampai tak terhingga sehingga dapat dinyatakan bahwa model berdistribusi normal.

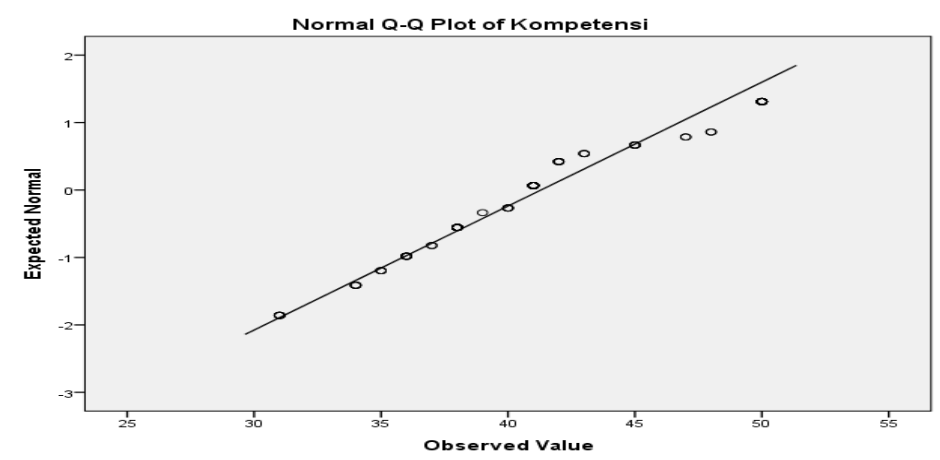

Gambar 4 : Uji Asumsi Normalitas Plot Kompetensi Pendamping

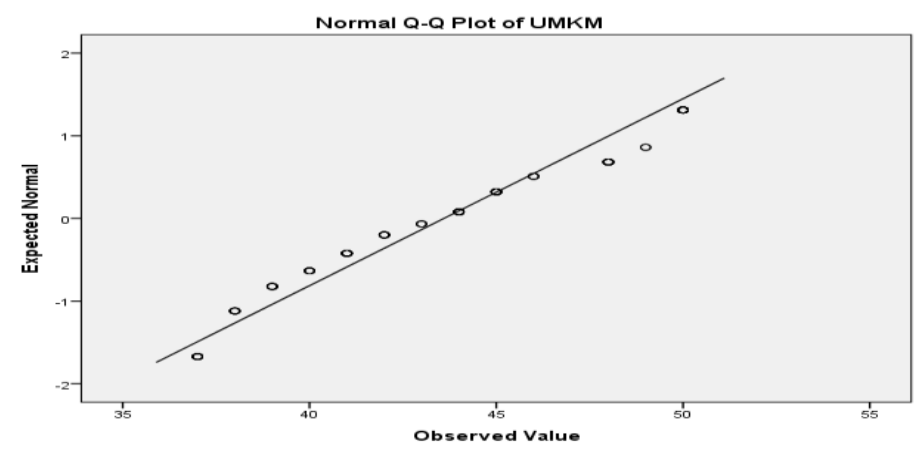

Gambar 5 : Uji Asumsi Normalitas Plot UMKM

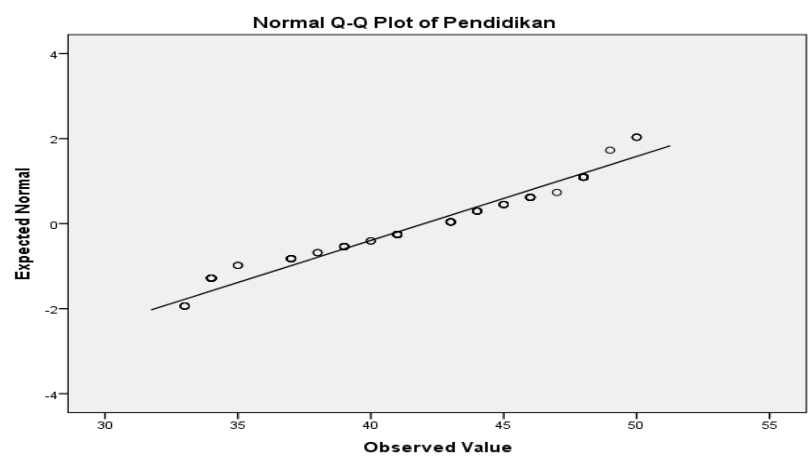

Gambar 6 : Uji Asumsi Normalitas Plot Pendidikan Anak Peserta

Berdasarkan Gambar diatas menunjukkan bahwa plot penyebaran data berada disekitar dan disepanjang garis, karena itu dapat dinyatakan penyebaran data variabel berdistribusi normal.

\section{Uji Heteroskedastisitas}


Hasil uji heteroskedastisitas yang ditunjukkan oleh hasil output program SPSS versi 22 adalah sebagai berikut:

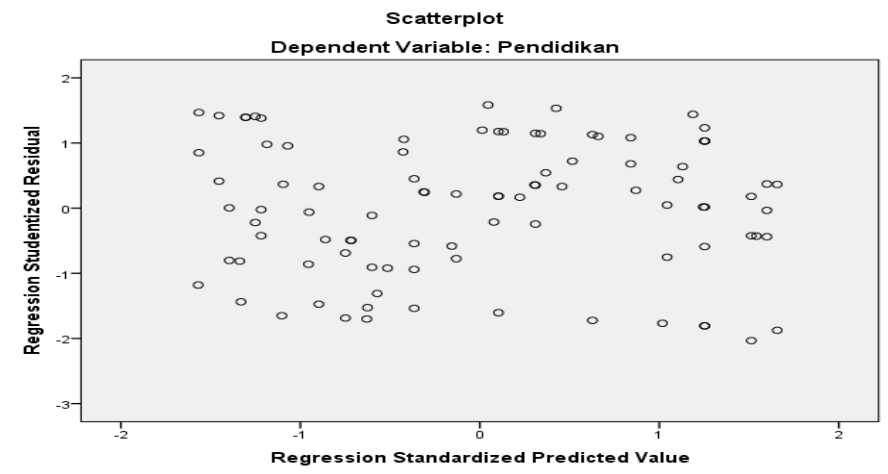

Gambar 7 : Uji Heteroskedastisitas Scatterplot

Dengan melihat gambar di atas, menunjukkan titik-titik menyebar secara di atas dan dibawah angka nol pada sumbu $\mathrm{Y}$, dan tidak membentuk pola tertentu. Hal ini mengindikasikan tidak terjadi heteroskedastisitas pada model regresi sehingga model regresi layak dipakai.

\section{Uji Multikolinearitas}

Hasil uji multikolinearitas yang diperoleh dari hasil output program SPSS versi 22 adalah sebagai berikut:

\begin{tabular}{|c|c|c|c|c|c|c|c|}
\hline \multirow[b]{5}{*}{ Model } & \multicolumn{5}{|c|}{ Coefficients $^{\text {a }}$} & \\
\hline & \multirow{3}{*}{\multicolumn{2}{|c|}{$\begin{array}{c}\text { Unstandardized } \\
\text { Coefficients } \\
\text { Std. }\end{array}$}} & \multirow{2}{*}{\multicolumn{2}{|c|}{$\begin{array}{l}\text { Standardized } \\
\text { Coefficients }\end{array}$}} & \multirow{3}{*}{\multicolumn{3}{|c|}{$\begin{array}{l}\text { Collinearity } \\
\text { Statistics } \\
\text { Toleran }\end{array}$}} \\
\hline & & & & & & & \\
\hline & & & & & & & \\
\hline & B & Error & Beta & $\mathrm{t}$ & Sig. & ce & VIF \\
\hline 1 (Constant) & 35.394 & 5.759 & & 6.146 & .000 & & \\
\hline Kompetensi & -.021 & .102 & -.023 & -.208 & .836 & .900 & 1.111 \\
\hline UMKM & .172 & .125 & .150 & 1.371 & .174 & .900 & 1.111 \\
\hline
\end{tabular}

Berdasarkan Tabel 6 diatas, menunjukkan bahwa nilai VIF adalah sebesar 11.282 dan tolerance sebesar 0,900 dengan kriteria uji yaitu jika nilai $\mathrm{VIF}<1,111$ dan nilai tolerance $>1,0$ maka dapat dinyatakan tidak ada hubungan linear antar variabel independen dalam model regresi, sehingga tidak ada persoalan multikolinearitas di dalam model.

\section{d) Analisis Korelasi}

Metode analisis korelasi dapat diketahui hubungan antara variabel dengan melihat pearson correlation hasil output program SPSS versi 22 sebagai berikut:

Tabel 7 : Analisis Korelasi

\begin{tabular}{lcccc}
\hline & \multicolumn{3}{c}{ Model Summary $^{\mathrm{b}}$} \\
Model & $\mathrm{R}$ & R Square & $\begin{array}{c}\text { Adjusted R } \\
\text { Square }\end{array}$ & $\begin{array}{c}\text { Std. Error of the } \\
\text { Estimate }\end{array}$ \\
\hline 1 & $.144^{\mathrm{a}}$ & .021 & -.001 & 5.06051 \\
$\begin{array}{l}\text { a. Predictors: (Constant), UMKM, Kompetensi } \\
\text { b. Dependent Variable: Pendidikan }\end{array}$ & & \\
\hline
\end{tabular}


Berdasarkan Tabel 7 diatas, menunjukkan bahwa hasil analisis korelasi (r) adalah sebesar 0,144. Hal ini menyatakan bahwa keeratan hubungan antara Kompetensi Pendamping PKH dengan UMKM terhadap Pendidikan Anak Peserta PKH sangat kuat karena nilai r 0,144 > 0,5.

\section{e) Uji Regresi Linear Berganda}

Hasil analisis regresi linear berganda dapat dilihat pada tabel berikut:

Tabel 8 : Uji Regresi Linear Berganda

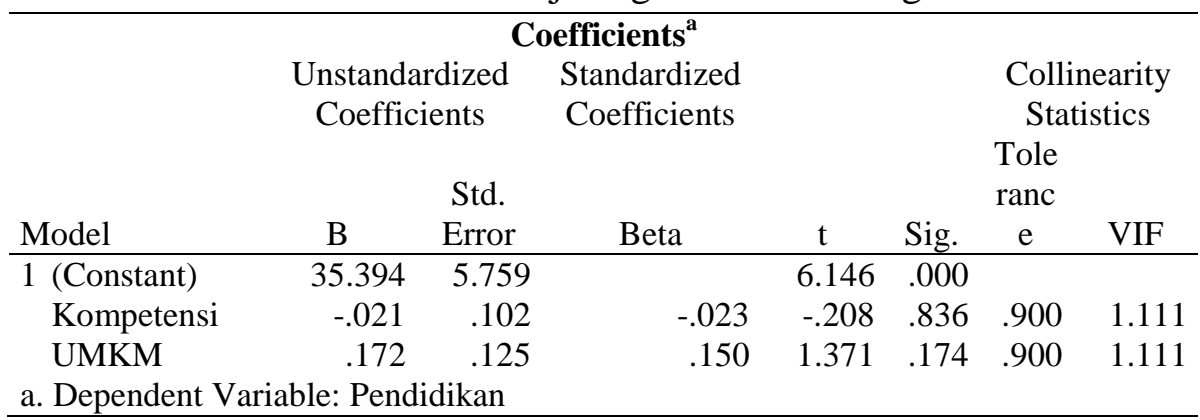

Berdasarkan Tabel 8 diatas, maka dapat diuraikan persamaan regresi linear berganda sebagai berikut:

$\mathrm{Y}=35.394+\mathrm{b}_{1} \mathrm{X}_{1}+\mathrm{b}_{2} \mathrm{X}_{2}$

$\mathrm{Y}=35.394+(-.021) \mathrm{X}_{1}+0.172 \mathrm{X}_{2}$

Berdasarkan persamaan regresi tersebut, nilai konstanta variabel Pendidikan Anak Peserta PKH (Y) adalah sebesar 35.394, hal ini berarti jika tidak ada variabel Kompetensi Pendamping PKH dan UMKM atau $\mathrm{X}_{1}$ dan $\mathrm{X}_{2}=0$, maka Pendidikan Anak Peserta PKH akan tetap sebesar 35.394 satuan. Nilai variabel Kompetensi Pendamping PKH $\left(\mathrm{X}_{1}\right)$ sebesar 0,021 dan bertanda negatif, ini menunjukkan bahwa Kompetensi Pendamping PKH mempunyai hubungan yang berlawanan arah dengan risiko sistematis. Hal ini mengandung arti bahwa setiap kenaikan Kompetensi Pendamping PKH satu satuan maka variabel Pendidikan Anak Peserta PKH (Y) akan turun sebesar 0,021 dengan asumsi bahwa variabel bebas yang lain dari model regresi adalah tetap. Nilai koefisien UMKM $\left(\mathrm{X}_{2}\right)$ sebesar 0.172 sehingga dengan asumsi variabel bebas yang lain dari model regresi adalah tetap.

f)

\section{Koefisien Determinasi $\left(\mathbf{R}^{2}\right)$}

Hasil uji koefisien determinasi melalui program SPSS versi 22 adalah sebagai berikut: Tabel 9 : Uji Koefisien Determinasi

\begin{tabular}{llccc}
\hline & \multicolumn{3}{c}{ Model Summary $^{\mathbf{b}}$} \\
Model & $\mathrm{R}$ & $\mathrm{R}$ Square & $\begin{array}{c}\text { Adjusted R } \\
\text { Square }\end{array}$ & $\begin{array}{c}\text { Std. Error of the } \\
\text { Estimate }\end{array}$ \\
\hline 1 & $.144^{\mathrm{a}}$ & .021 & -.001 & 5.06051 \\
$\begin{array}{l}\text { a. Predictors: (Constant), UMKM, Kompetensi } \\
\text { b. Dependent Variable: Pendidikan }\end{array}$ & & \\
\hline
\end{tabular}

Berdasarkan Tabel 9 diatas, diperoleh $\mathrm{R}^{2}$ sebesar 0,021, didapat dari nilai $\mathrm{R}=0,144$ maka $\mathrm{R}^{2}$ dapat diketahui untuk menghitung koefisien determinasi (KD) adalah $\mathrm{R}^{2}$ X $100 \%$ maka 0,144 x $100 \%$ adalah 14,4 \%. Sehingga dapat disimpulkan bahwa kontribusi Kompetensi Pendamping PKH $\left(\mathrm{X}_{1}\right)$ dan UMKM $\left(\mathrm{X}_{2}\right)$ mempengaruhi terhadap Pendidikan Anak Peserta PKH (Y) adalah 
sebesar $14,4 \%$, sedangkan sisanya $85,6 \%$ dipengaruhi variabel lainnya yang tidak dijelaskan dalam penelitian ini.

\section{b. Pengujian Hipotesis}

\section{Pengujian Hipotesis Secara Parsial (uji-t)}

Derajat kepercayaan yang digunakan adalah 0,05 , apabila nilai $t_{\text {hitung }}>t_{\text {tabel }}$ maka $\mathrm{H}_{0}$ ditolak yang berarti terdapat pengaruh variabel bebas secara parsial terhadap variabel terikat.

\section{Uji-t Kompetensi Pendamping PKH Terhadap Pendidikan Anak Peserta}

Hasil output program SPSS versi 22 mengenai uji secara parsial:

Tabel 10 : Uji Parsial Kompetensi Pendamping PKH Terhadap Pendidikan

\begin{tabular}{|c|c|c|c|c|c|c|c|}
\hline \multirow[b]{3}{*}{ Model } & \multicolumn{5}{|c|}{ Coefficients $^{\mathrm{a}}$} & \multirow{2}{*}{\multicolumn{2}{|c|}{$\begin{array}{l}\text { Collinearity } \\
\text { Statistics }\end{array}$}} \\
\hline & \multicolumn{2}{|c|}{$\begin{array}{c}\text { Unstandardized } \\
\text { Coefficients } \\
\text { Std. }\end{array}$} & \multicolumn{2}{|l|}{$\begin{array}{l}\text { Standardized } \\
\text { Coefficients }\end{array}$} & \multirow[b]{2}{*}{ Sig. } & & \\
\hline & $\mathrm{B}$ & Error & Beta & $\mathrm{t}$ & & Tolerance & VIF \\
\hline 1 (Constant) & 35.394 & 5.759 & & 6.146 & .000 & & \\
\hline Kompetensi & -.021 & .102 & -.023 & -.208 & .836 & .900 & 1.111 \\
\hline UMKM & .172 & .125 & .150 & 2.371 & .174 & .900 & 1.111 \\
\hline
\end{tabular}

Hipotesis pertama, dalam penelitian ini adalah sebagai berikut:

$\mathrm{H}_{0}$ tidak terjadi pengaruh antara Kompetensi Pendamping PKH $\left(\mathrm{X}_{1}\right)$ terhadap Pendidikan Anak

Peserta PKH (Y).

$\mathrm{H}_{1}$ terdapat pengaruh antara Kompetensi Pendamping $\mathrm{PKH}\left(\mathrm{X}_{1}\right)$ terhadap Pendidikan Anak Peserta PKH (Y).

Berdasarkan Tabel 10 diatas, dapat diketahui bahwa nilai $t_{\text {hitung }}=0,208$. Sedangkan untuk mencari $t_{\text {tabel }}$ menggunakan rumus:

$$
\mathrm{t}_{\text {tabel }}=\mathrm{t}(\alpha / 2 ; \mathrm{n}-\mathrm{k}-1)=\mathrm{t}(0,025 ; 91)=2,000
$$

Dari data diatas, diketahui nilai $\mathrm{t}_{\text {hitung }}$ lebih besar dari $\mathrm{t}_{\text {tabel }}(0,208>2,000)$ sehingga $\mathrm{H}_{0}$ ditolak, yang berarti tidak terdapat pengaruh Kompetensi Pendamping PKH terhadap Pendidikan Anak Peserta PKH

\section{Uji-t UMKM Terhadap Pendidikan Anak Peserta PKH}

Hasil output program SPSS versi 22 mengenai uji secara parsial:

Tabel 11 : Uji Parsial UMKM Terhadap Pendidikan Anak Peserta PKH

\begin{tabular}{|c|c|c|c|c|c|c|c|}
\hline \multirow[b]{3}{*}{ Model } & \multicolumn{5}{|c|}{ Coefficients $^{\mathrm{a}}$} & \multirow{2}{*}{\multicolumn{2}{|c|}{$\begin{array}{c}\text { Collinearity } \\
\text { Statistics }\end{array}$}} \\
\hline & \multicolumn{2}{|c|}{$\begin{array}{c}\text { Unstandardized } \\
\text { Coefficients } \\
\text { Std. }\end{array}$} & \multicolumn{2}{|l|}{$\begin{array}{l}\text { Standardized } \\
\text { Coefficients }\end{array}$} & \multirow[b]{2}{*}{ Sig. } & & \\
\hline & B & $\begin{array}{l}\text { Std. } \\
\text { Error }\end{array}$ & Beta & $\mathrm{t}$ & & Tolerance & VIF \\
\hline 1 (Constant) & 35.394 & 5.759 & & 6.146 & .000 & & \\
\hline Kompetensi & -.021 & .102 & -.023 & -.208 & .836 & .900 & 1.111 \\
\hline UMKM & .172 & .125 & .150 & 2.371 & .174 & .900 & 1.111 \\
\hline
\end{tabular}

a. Dependent Variable: Pendidikan

Hipotesis pertama, dalam penelitian ini adalah sebagai berikut:

$\mathrm{H}_{0}$ tidak terjadi pengaruh antara UMKM $\left(\mathrm{X}_{2}\right)$ terhadap Pendidikan Anak Peserta PKH (Y) di

Kecamatan Ciruas Kabupaten Serang.

$\mathrm{H}_{1}$ terdapat pengaruh antara UMKM $\left(\mathrm{X}_{2}\right)$ terhadap Pendidikan Anak Peserta PKH (Y) di Kecamatan Ciruas Kabupaten Serang.

Berdasarkan Tabel 11 diatas, dapat diketahui bahwa nilai $t_{\text {hitung }}=2,371$. Sedangkan untuk mencari $t_{\text {tabel }}$ menggunakan rumus: 


$$
\mathrm{t}_{\text {tabel }}=\mathrm{t}(\alpha / 2 ; \mathrm{n}-\mathrm{k}-1)=\mathrm{t}(0,025 ; 91)=2,000
$$

Dari data diatas, diketahui nilai $\mathrm{t}_{\text {hitung }}$ lebih besar dari $\mathrm{t}_{\text {tabel }}(2,371>2,000)$ sehingga $\mathrm{H}_{0}$ diterima, yang berarti terdapat pengaruh UMKM terhadap Pendidikan Anak Peserta PKH di Kecamatan Ciruas Kabupaten Serang.

\section{Pengujian Hipotesis Secara Simultan (Uji-F)}

Jika $F_{\text {hitung }}>F_{\text {tabel }}$ atau Sig $\mathrm{F}<0,05$ maka menerima $\mathrm{H}_{1}$ dan menolak $\mathrm{H}_{0}$, maka variabel Kompetensi Pendamping PKH dan UMKM berpengaruh secara signifikan terhadap Pendidikan Anak Peserta $\mathrm{PKH}$, dan jika nilai $\mathrm{F}_{\text {hitung }}<\mathrm{F}_{\text {tabel }}$ atau Sig $\mathrm{F}>0,05$ maka menolak $\mathrm{H}_{1}$ dan menerima $\mathrm{H}_{0}$, maka variabel Kompetensi Pendamping PKH dan variabel UMKM secara simultan tidak terdapat pengaruh signifikan terhadap Pendidikan Anak Peserta PKH. Berikut hipotesis variabel Kompetensi Pendamping PKH dan UMKM terhadap Pendidikan Anak Peserta PKH dengan menggunakan uji-F.

$\mathrm{H}_{0}$ tidak terdapat Kompetensi Pendamping PKH dan UMKM secara simultan mempunyai pengaruh yang signifikan terhadap Pendidikan Anak

$\mathrm{H}_{\mathrm{a}}$ terdapat Kompetensi Pendamping PKH dan UMKM secara simultan mempunyai pengaruh yang signifikan terhadap Pendidikan Anak

Hasil uji-F dapat dilihat berikut ini:

Tabel 12 : Uji Simultan Kompetensi Pendamping PKH Dan UMKM Terhadap Pendidikan Anak Peserta PKH

\begin{tabular}{|c|c|c|c|c|c|c|}
\hline \multicolumn{7}{|c|}{ ANOVA $^{\mathbf{a}}$} \\
\hline \multicolumn{2}{|c|}{ Model } & $\begin{array}{l}\text { Sum of } \\
\text { Squares }\end{array}$ & $\mathrm{df}$ & $\begin{array}{l}\text { Mean } \\
\text { Square }\end{array}$ & $\mathrm{F}$ & Sig. \\
\hline 1 & Regression & 49.607 & 2 & 24.804 & 12.969 & $.384^{b}$ \\
\hline & Residual & 2330.393 & 91 & 25.609 & & \\
\hline & Total & 2380.000 & 93 & & & \\
\hline
\end{tabular}

a. Dependent Variable: Pendidikan

b. Predictors: (Constant), UMKM, Kompetensi

Berdasarkan tabel diatas, dapat diketahui bahwa nilai $\mathrm{F}_{\text {hitung }}=12,969$. Derajat kepercayaan yang digunakan adalah $5 \%$ maka nilai $\mathrm{F}_{\text {tabel }}$ dapat diketahui dari rumus:

$$
\mathrm{F}_{\text {tabel }}=\mathrm{F}(\mathrm{k} ; \mathrm{n}-\mathrm{k})=\mathrm{F}(2 ; 92)=3,10
$$

Berdasarkan data diatas, diperoleh $\mathrm{F}_{\text {hitung }}>\mathrm{F}_{\text {tabel }}(12,969>3,10)$ dan nilai Sig $\mathrm{F}<\alpha(0,000<$ 0,05), maka dapat diambil kesimpulan bahwa terdapat pengaruh signifikan Kompetensi Pendamping PKH dan UMKM secara simultan terhadap Pendidikan Anak Peserta PKH.

\section{c. Pembahasan Hasil Penelitian}

Hasil pengujian analisis regresi linear berganda menunjukkan bahwa nilai konstanta rumus variabel Pendidikan Anak Peserta PKH adalah $\left.\mathrm{Y}=35.394+(-0.021) \mathrm{X}_{1}+0.172 \mathrm{X}_{2}\right)$, berarti jika tidak ada variabel Kompetensi Pendamping PKH dan UMKM maka variabel Pendidikan Anak Peserta PKH akan tetap sebesar 35.394 satuan. Variabel kompetensi pendamping PKH menunjukkan tanda negatif yang berarti kompetensi pendamping PKH mempunyai hubungan yang berlawanan arah dengan UMKM, jadi jika kompetensi pendamping PKH dinaikkan satu satuan maka akan berpengaruh menurunkan Pendidikan Anak Peserta PKH sebesar 0,021 satuan, sedangkan jika variabel UMKM dinaikkan sebesar satu satuan, maka akan berpengaruh meningkatkan kinerja sebesar 0,172 satuan. 
Hasil analisis korelasi sederhana (r) didapat nilai sebesar 0,144, artinya bahwa keeratan hubungan antara variabel Kompetensi Pendamping PKH dan UMKM terhadap Pendidikan Anak Peserta PKH adalah kuat karena nilai $0,144>0,5$ dan berada pada rentang rendah yaitu $(0,00-0,20)$. Besarnya kontribusi variabel bebas ditentukan oleh koefisien determinasi dan didapat perhitungan sebesar 14,4 \%, berarti variabel Kompetensi Pendamping PKH dan UMKM mempengaruhi Pendidikan Anak Peserta PKH sebesar 14,4\% , dan sisanya 85,6\% dipengaruhi oleh variabelvariabel lain yang tidak dijelaskan dalam model penelitian ini.

Berdasarkan uji hipotesis diperoleh nilai $\mathrm{F}_{\text {hitung }}$ sebesar 12,969> $\mathrm{F}_{\text {tabel }}$ sebesar 3,10 dan nilai Sig F sebesar $0,000<0,05$ maka terdapat pengaruh signifikan antara Kompetensi Pendamping PKH dan UMKM terhadap Pendidikan Anak Peserta PKH di Kecamatan Ciruas Kabupaten Serang.

\section{KESIMPULAN}

Berdasarkan hasil penelitian menunjukkan nilai konstanta rumus variabel Pendidikan Anak Peserta $\mathrm{PKH}$ adalah $\mathrm{Y}=35.394+(-0.021) \mathrm{X}_{1}+0.172 \mathrm{X}_{2}$, berarti jika tidak ada variabel kompetensi pendamping PKH dan UMKM maka variabel pendidikan anak peserta PKH akan tetap sebesar 35.394 satuan. Besarnya kontribusi variabel bebas ditentukan oleh koefisien determinasi dan di dapat perhitungan sebesar 14,4\%, berarti variabel kompetensi pendamping PKH dan UMKM mempengaruhi Pendidikan Anak sebesar 14,4\%, dan sisanya 85,6\% dipengaruhi oleh variabel-variabel lain yang tidak dijelaskan dalam penelitian ini.

Sedangkan hasil uji hipotesis diperoleh nilai $\mathrm{F}_{\text {hitung }}$ sebesar 12,969 lebih besar dari $\mathrm{F}_{\text {tabel }}$ sebesar 3,10 dan nilai Sig F sebesar $0,000<0,05$ maka terdapat pengaruh signifikan antara Kompetensi Pendamping PKH dan UMKM terhadap Pendidikan Anak Peserta PKH di Kecamatan Ciruas Kabupaten Serang.

\section{DAFTAR PUSTAKA}

Leahy, L. (2001). Siapakah Manusia. Yogyakarta: Kenisius.

Mugniesyah, S. (2005). Manajemen Pelatihan. Bogor: Depatemen Komunikasi dan Pengembangan Masyarakat, IPB.

Mulyasa. (2011). Kurikulum Berbasis Kompetensi. Bandung: Remaja Rosdakarya.

Sugiyono. (2014). Metode Penelitian Pendidikan Pendekatan Kuantitatif, Kualitatif dan R\&D. Bandung: Alfabeta.

Tim Penyusun. (2009). Pedoman Operasional Program Keluarga Harapan (PKH). Jakarta: Kementerian Sosial. 